\title{
Lelis syndrome
}

INSERM

\section{Source}

INSERM. (1999). Orphanet: an online rare disease and orphan drug data base. Lelis syndrome. ORPHA:140936

Lelis syndrome is characterised by the association of ectodermal dysplasia (hypotrichosis and hypohidrosis) with acanthosis nigricans. 